\title{
OPEN Author Correction: Multimodal hippocampal subfield grading for Alzheimer's disease classification
}

\section{Kilian Hett $『$, Vinh-Thong Ta, Gwenaëlle Catheline, Thomas Tourdias, José V. Manjón, Pierrick Coupé \& Alzheimer's Disease Neuroimaging Initiative}

Correction to: Scientific Report https://doi.org/10.1038/s41598-019-49970-9, published online 25 September 2019.

The original version of this Article contained an error in Affiliation 8, which was incorrectly given as 'Universitat Politècnia de València, ITACA, 46022, Valencia, Spain'. The correct Affiliation is listed below:

Universitat Politècnica de València, ITACA, 46022, Valencia, Spain.

This error has now been corrected in the HTML and PDF versions of the Article.

\begin{abstract}
(c) (1) Open Access This article is licensed under a Creative Commons Attribution 4.0 International License, which permits use, sharing, adaptation, distribution and reproduction in any medium or format, as long as you give appropriate credit to the original author(s) and the source, provide a link to the Creative Commons license, and indicate if changes were made. The images or other third party material in this article are included in the article's Creative Commons license, unless indicated otherwise in a credit line to the material. If material is not included in the article's Creative Commons license and your intended use is not permitted by statutory regulation or exceeds the permitted use, you will need to obtain permission directly from the copyright holder. To view a copy of this license, visit http://creativecommons.org/licenses/by/4.0/.
\end{abstract}

(C) The Author(s) 2020 